Newfoundland and Labrador Studies

\title{
The Newfoundland Railway, Freight Rates, and the Terms of Union between Newfoundland and Canada
}

\section{Peter Neary}

Volume 34, Number 1, 2019

URI: https://id.erudit.org/iderudit/1072438ar

DOI: https://doi.org/10.7202/1072438ar

See table of contents

Publisher(s)

Faculty of Arts, Memorial University

\section{ISSN}

1719-1726 (print)

1715-1430 (digital)

Explore this journal

Cite this article

Neary, P. (2019). The Newfoundland Railway, Freight Rates, and the Terms of Union between Newfoundland and Canada. Newfoundland and Labrador Studies, 34(1), 93-129. https://doi.org/10.7202/1072438ar viewed online.

https://apropos.erudit.org/en/users/policy-on-use/ 


\section{The Newfoundland Railway, Freight Rates, and the Terms of Union between Newfoundland and Canada}

Peter Neary

The history of the origins of the Terms of Union between Newfoundland and Canada - a constitutional document - has been studied extensively, and there is a growing body of scholarship about the specific terms that have been fought over since union took effect in 1949. In 1959, Term 29, which promised a review and adjustment of Newfoundland's financial position within Confederation, ignited a battle royal between St. John's and Ottawa, an episode well documented in Raymond B. Blake's 2015 study, Lions or Jellyfish:Newfoundland-Ottawa Relations since 1957. In 1984, in a decision that triggered the events leading to the 1985 Atlantic Accord, the Supreme Court of Canada ruled that jurisdiction over the resources under the seabed off Newfoundland belonged to Canada. Not surprisingly, Ottawa's jurisdiction over fisheries matters has been a continuing source of friction with an ocean province. In the 1990s, Term 17, which dealt with education rights, was back in the news, when the province moved against its publicly funded denominational system of education; to achieve its purpose, using a procedure specified in the Constitution Act, 1982, Newfoundland secured two amendments to Term 17, the first in 1997 and the second in 1998. In 2001, in another action made possible by the same Act, the name of the province was changed from "Province of Newfoundland" to "Province of Newfoundland and Labrador." In 2011, understanding of how Newfoundland was fitted into the Canada of the 1940s was advanced by the publication of Corey Slumkoski's 
Inventing Atlantic Canada: Regionalism and the Maritime Reaction to Newfoundland's Entry into Canadian Confederation; and in a comprehensive 2012 article in this journal about the "Roads-for-Rails"(1988) and "Roads-for-Boats" (1997) federal-provincial agreements, Jeffrey F. Collins broke new research ground regarding the arrangement made under Term 31 whereby Canada took over "the Newfoundland Railway, including steamship and other marine services." ${ }^{1}$

The purpose of the present paper is to look in detail at the making of the related Term 32 and the long and complex history of litigation regarding it that began in the early 1950s and continued into the twenty-first century. This litigation mainly concerned railway freight rates through changing transportation circumstances, but the recent focus of contention - in Oceanex Inc. v. Canada (Minister of Transport) - has been the application of national transportation policy to freight rates on the constitutionally guaranteed ferry service between Port aux Basques, Newfoundland and Labrador, and North Sydney, Nova Scotia. By definition, Terms 31 and 32 loom large in the history of federalprovincial relations vis-à-vis Canada's tenth province.

In mid-1946 the people of Newfoundland and Labrador, who had been living since 16 February 1934 under a British-appointed Commission of Government, elected members to a National Convention. ${ }^{2}$ As specified in the governing legislation, their task was:

to consider and discuss among themselves as elected representatives of the people of Newfoundland the changes that have taken place in the commercial and economic situation of the Island since 1934, and bearing in mind the extent to which the high revenues of recent years have been due to wartime conditions to examine the position of the country and to make recommendations to His Majesty's Government in the United Kingdom as to possible 
forms of future government to be put before the people at a national referendum. ${ }^{3}$

The convention, therefore, was an advisory rather than a legislative body, with the United Kingdom reserving to itself the last word on the substance of the forthcoming referendum.

At the time, the Newfoundland Railway was one of the country's biggest enterprises and major employers, and, not surprisingly, its affairs loomed large in the proceedings of the National Convention, which began meeting in the Colonial Building in St.John's on 11 September 1946. Launched in the late nineteenth century as a private enterprise, though with healthy government support, the railway, which was of narrow rather than standard gauge, had been publicly owned since 1923. In 1947, it had a main line of 547.22 miles running from St. John's to Port aux Basques, five branch lines, total track of 705.13 miles, and 3,700 employees. ${ }^{4}$ In addition to its land operations, it ran a coastal boat service and a ferry service, dating from 1898, that linked Port aux Basques and North Sydney across the Cabot Strait, Gulf of St. Lawrence. For a time the Gulf ferry service had attracted Canadian subsidy, but this had disappeared when the railway had been taken over by the Newfoundland government. ${ }^{5}$ Subsequently, Newfoundland had attempted to extract further Canadian subsidy by tying the matter to trade negotiations, but nothing had come of this and by the 1940s the issue was lost in the fog of time. For most of its history under public ownership the railway system had lost money but, thanks to wartime prosperity, it turned profits in 1940-44. ${ }^{6}$ In $1945-46$ its operating revenue was $\$ 11,140,417$ and its operating expenses $\$ 12,456,616$.

To get on with its work leading to the recommendation to London of possible constitutional options, the National Convention formed 13 committees. One of them was devoted to transportation and communications and was chaired by Joseph Roberts Smallwood, the member for Bonavista Centre. A radical with a checkered past, he became the leading advocate in the National Convention for Confederation with Canada. The committee he chaired investigated "six 
activities of the government," one of them being the Newfoundland railway system. ${ }^{7}$ The Convention likewise voted to send exploratory delegations first to London and then to Ottawa. The London delegation received a decidedly cool reception: facing post-war adversity and retreat from empire, the British were anxious to dismantle the Commission of Government and favoured the union of Newfoundland with Canada, an objective they had been pushing for behind the scenes. By contrast, the delegation to Ottawa was warmly received. Its task was to ascertain what "fair and equitable basis" might exist for the federal union of the two countries. ${ }^{8}$

The Ottawa delegation was chaired by F. Gordon Bradley, the sitting chair of the National Convention, and had as its other members Smallwood, T.G.W. Ashbourne (Twillingate), Charles Ballam (Humber), Lester Burry (Labrador), P.Wellington Crummey (Bay de Verde), and Gordon F. Higgins (St. John's City [East]).It was welcomed to the Canadian capital by Prime Minister William Lyon Mackenzie King at a ceremony held in the Railway Committee Room of the House of Commons on the morning of 25 June 1947. ${ }^{9}$ Substantive talks between the two sides began that afternoon, when Canadian Secretary of State for External Affairs Louis St. Laurent was chosen to chair proceedings, and it was agreed that no verbatim transcript of discussions would be kept. ${ }^{10}$ On this occasion also the Newfoundland delegation submitted a memorandum detailing Newfoundland services that, in the event of union, "would appear to fall in the federal sphere."

In the fall of 1945, anticipating the negotiations that had now come to pass, Canada had appointed a cabinet committee on Newfoundland, which was advised by an interdepartmental committee on Canadian-Newfoundland relations. ${ }^{11}$ The interdepartmental committee, chaired by R.A. MacKay, had begun meeting in May $1946 .{ }^{12}$ During the war MacKay had left his position as Eric Dennis Memorial Professor of Government and Political Science at Dalhousie University for the post of special assistant in the Department of External Affairs. He was arguably Ottawa's leading expert on Newfoundland affairs and in 1946 edited Nerwfoundland: Economic, Diplomatic, and 
Strategic Studies, published by Oxford University Press under the auspices of the Royal Institute of International Affairs. He was at the fore in facilitating the 1947 negotiations, and his papers, now part of the collections of Library and Archives Canada, are a rich source for understanding both what happened in the talks with the Newfoundland delegation and subsequent events. ${ }^{13}$

At a plenary session of the two delegations held on 7 July, it was decided that the conversations "had reached a point where subcommittees might profitably be set up to explore more fully and more expeditiously than would be practicable in general meetings a number of subjects which would require to be dealt with in detail as a preliminary to considering the question of a basis of union. ${ }^{14}$ One of the subcommittees created was devoted to transportation and had as its Canadian members Transport Minister Lionel Chevrier, Deputy Minister of Transport C.P. Edwards, S.W. Fairweather of Canadian National Railways (CNR/CN), and H.J. Rahlves of the Park Steamship Company, a federal Crown corporation. The Newfoundland members were Ballam, Higgins, and Smallwood. The task of the subcommittee was "to bring together information on the Newfoundland Railway and Steamship Services with a view to enabling the Canadian representatives to examine the problems that would be involved, in the event of union, in the integration of the Newfoundland Government Railway and Steamship Services with the Canadian transportation system." ${ }^{15}$ Another subcommittee addressed the matter of Maritime freight rates, which had preferred status in Canada under the terms of the Maritime Freight Rates Act, 1927. Its members were Edwards and Fairweather for Canada and Ballam, Crummey, and Smallwood for Newfoundland; its job was "to examine information on the reduced freight rates accorded to goods moving within or out of the Maritime region of Canada and the applicability, in the event of union with Canada, of such reduced rates to products moving within or out of Newfoundland." ${ }^{16}$

The information gathered by the investigative subcommittees was co-ordinated by another subcommittee, which had as its Canadian members Finance Minister J.L. Ilsley and National Revenue Minister 
J.J. McCann, assisted by MacKay, Mitchell Sharp (Department of Finance), and other officials as required. Their Newfoundland counterparts on this drafting committee were Ashbourne, Higgins, and Smallwood. After this working group had examined "the various reports submitted" and discussed "the means whereby the principal issues involved in union might be met," the Canadian members undertook "to report promptly to the Cabinet Committee regarding a basis for union which might be fair and equitable to both Newfoundland and Canada." ${ }^{17}$ On the agenda of the drafting committee for its meeting of 29 August the question was raised "Whether anything is to be included covering steamship connections between Port Aux Basques and North Sydney." 18 According to a notation on MacKay's copy of this document, the matter was referred for advice to J.R. Baldwin, assistant secretary to the cabinet.

In the event, the first draft of the document entitled "Basis for the admission of Newfoundland as a Province of Canada," dated 23 September 1947, provided, inter alia, as follows:

\section{TRANSPORTATION}

The Government of Canada, either directly or through an appropriate Government agency, will maintain steamship services between North Sydney and Port aux Basques in accordance with the traffic offering, and on completion of a motor highway between Corner Brook and Port aux Basques will make provision for a suitable service for the carriage of motor vehicles between North Sydney and Port aux Basques.

13. Railway services and railway rates over the Newfoundland Railway will be subject to regulation by the Board of Transport Commissioners of Canada similarly to railway services and rates elsewhere in Canada. For the purpose of rate regulation through traffic moving between North Sydney and Port aux Basques shall be treated as all-rail traffic. The province of Newfoundland shall also be deemed to be within the Maritime region of Canada, and 
any legislation of the Parliament of Canada, such as the Maritime Freight Rates Act, 1927, and amendments, providing for special rates on freight within, into or out of the Maritime region shall, so far as appropriate, be deemed to apply to Newfoundland. ${ }^{19}$

A suggested alternative wording to item 12 , deemed to be preferable in the draft, read:

An efficient steamship service for the conveyance of mails, passengers and freight shall be maintained between the Island and the Mainland by the Government of Canada.

As will be seen, however, this wording was ultimately passed over.

With Bradley under mounting pressure to return to St. John's and call the National Convention back into session (it had adjourned on 26 May), the Newfoundland delegates were anxious to leave Ottawa with a Canadian offer of terms of union in hand. But this objective was put beyond reach on 10 August when Frank Bridges, Canada's Minister of Fisheries and New Brunswick's representative in the cabinet, died suddenly. On 2 September Milton F. Gregg, another New Brunswicker, was sworn in as Minister of Fisheries, but Prime Minister King was unwilling to proceed with an offer to Newfoundland pending a by-election in Bridges's seat of York-Sunbury, which Gregg would now contest on behalf of the governing Liberal Party. King believed that New Brunswick "was dead against Newfoundland coming in on practically any terms" and that the Progressive Conservative candidate in York-Sunbury would be helped "if anything were said which indicated we were keen on having Newfoundland brought in." ${ }^{20}$ In the circumstances, King was against giving "any assurance" to the Newfoundland delegates that the Canadian government's decision "would be made known at a specific date." The "most" that King was willing to proffer was that Canada's decision "would be given as expeditiously as circumstances would permit," after due consideration by cabinet. So 
worried was the prime minister about upsetting established provinces by a false move in relation to Newfoundland that he hesitated to act until every province was represented in his cabinet by an elected member of Parliament.

Thus, instead of returning home with draft terms of union, the Newfoundland delegation brought back a summary of proceedings in Ottawa, which was agreed to on 29 September at the final meeting between the two parties. ${ }^{21}$ The two-part summary, with 15 appendices and an annex, was entitled Meeting[s] between delegates for the National Convention of Nerwfoundland and representatives of the Government of Canada[:] Ottawa, June 25th-September 29th, 1947, Part I (Summary of Proceedings - Opening Statements[;] Documents Exchanged at Opening of Discussions), Part II (Answers to Questions - Submissions of Sub-Committees [-] List of Documents). On 11 October, when the National Convention resumed sitting, it was introduced at a stormy session that triggered Bradley's resignation as chairman (he was succeeded on 15 October by St. John's lawyer John Bernard McEvoy). ${ }^{22}$ Because of its black covers, the bulky two-part report was dubbed in the Convention the Black Books (or Black Book). Appendix VII gave a "preliminary statement of what would be involved in the integration of the Newfoundland government's railway and steamship services with the Canadian Railway System.” Dated July 1947, this was comprehensive in scope, and summarized thinking at the time on a major item of negotiation.

While the National Convention was digesting the Black Books, work proceeded in Ottawa on draft terms of union, with the way for approval cleared by Gregg's by-election win in York-Sunbury on 20 October. On 28 October, the Canadian cabinet approved the terms of an offer and this document was then sent to Governor Gordon Macdonald of Newfoundland for the attention of the National Convention. In his covering letter King set this limit on future negotiations: 
I feel I must emphasize that as far as the financial aspects of the proposed arrangements for union are concerned, the Government of Canada believes that the arrangements go as far as the Government can go under the circumstances. The Government could not readily contemplate any change in these arrangements which would impose larger financial burdens on Canada. On the other hand, with respect to those matters which are primarily of provincial concern, such as education, the Government of Canada would not wish to set down any rigid conditions, and it would be prepared to give reasonable consideration to suggestions for modifications or addition. ${ }^{23}$

Proposed arrangements for the Newfoundland Railway were detailed in two sections of Ottawa's offer. Clause 5 had this preamble: "At the union, or as soon as practicable thereafter, the following services will be taken over by Canada and become subject to the jurisdiction of Parliament, Newfoundland to be relieved of the public costs incurred in respect of each service after it is taken over." A 13-part list followed, with the first item being "The Newfoundland Railway, including steamship and other marine services." Clause 8 in turn listed 10 "public works and property" that would become the property of Canada when the service concerned was taken over pursuant to clause 5. At the head of this list was "The Newfoundland Railway, including rights of way, wharves, drydocks and other real property, rolling stock, equipment, ships and other personal property, Canada to assume the cost of the two steamships contracted for on behalf of the Railway and presently under construction in the United Kingdom." Under clause 16 the following related arrangements were proposed:

(1) Canada will maintain in accordance with the traffic offering a steamship service between North Sydney and Port aux Basques, which, on completion of a motor highway between Corner Brook and Port aux Basques, will include suitable provision for the carriage of motor vehicles. 
(2) Railway services and railway rates over the Newfoundland Railway will be subject to regulation by the Board of Transport Commissioners of Canada as are railway services and rates elsewhere in Canada.

(3) For the purpose of rate regulation:

(a) Through-traffic moving between North Sydney and Port aux Basques will be treated as all-rail traffic; (b) The Island of Newfoundland will be deemed to be within the Maritime region of Canada and any legislation of the Parliament of Canada (such as the Maritime Freight Rates Act, 1927, and amendments) providing for special rates on freight traffic moving within, into or out of, the Maritime region will, so far as appropriate, be made applicable to Newfoundland.

Clauses 5, 8, and 16 all had ample Canadian precedent and could readily be justified to existing provinces. The Canadian government owned a railway system; a ferry service had been promised to Prince Edward Island in its 1873 terms of union; the Board of Transport Commissioners had jurisdiction over the entire country; and the Maritime Freight Rates Act, 1927 — the product of the Maritime Rights movement of the 1920s - helped grease the wheels of Canadian federalism. Ottawa's bargaining with Newfoundland, moreover, took place against the background of rising tension within the Dominion about freight rates, a topic that was never far from a rolling boil in a continentwide federation of diverse regions. After the war, a spike in freight rates had triggered a protest movement, led by Nova Scotia and Manitoba, which mobilized the support of all provinces except Ontario and Quebec. ${ }^{24}$ In its dealings with Newfoundland, Ottawa had good reason to proceed cautiously, which it did.

On 6 November the Canadian offer reached the National Convention, where, thanks to its cover, it became known as the Grey Book, and a 
spirited debate about it began two weeks later. ${ }^{25}$ Smallwood, who had emerged as the leading advocate of union with Canada, was at the fore in pushing the proposal but failed to achieve necessary support. On 23 January 1948, as the Convention was finishing up its business, he introduced a resolution whereby Confederation with Canada would be one of the choices recommended to the British for inclusion on the referendum ballot, but on 29 January his resolution was defeated by a vote of 29-16. In the end, the advice of the National Convention to London was that in the planned referendum the voters be offered a choice between "Responsible Government as it existed prior to 1934" and "Commission of Government." ${ }^{26}$ The United Kingdom government, however, had the final say, and on 11 March 1948 it announced that the ballot would feature three choices - revised versions of the two options recommended by the National Convention and Confederation with Canada. On the ballot paper, the choices to be decided upon were given as "COMMISSION OF GOVERNMENT for a period of five years," "CONFEDERATION WITH CANADA," and "RESPONSIBLE GOVERNMENT as it existed in 1933."

The British now also ruled that the choice to be followed would have to have majority support among those who voted. Because there were three choices, this requirement might not be met on the first ballot. If this happened, the option with the lowest number of votes would be dropped and a second referendum held to decide between the other two constitutional choices. In practice, a second vote was indeed required; in the first referendum, held on 3 June, the Responsible Government option received the largest number of votes, with Confederation coming second, and Commission of Government a poor third. The runoff vote was then held on 22 July 1948; this time Confederation bested Responsible Government by 78,323 to 71,334 .

After Canada had made known its willingness to proceed on the basis of this result, the Commission of Government appointed a delegation 
to go to Ottawa to negotiate final terms of union. The delegation was chaired by Commissioner for Home Affairs and Education Albert J. Walsh, a Newfoundlander, ${ }^{28}$ and had six other members, including Bradley and Smallwood, the leader on the hustings in the rough-andtumble fight for Confederation. In preparation for its work in Ottawa, the delegation held a series of meetings in St. John's, beginning on 25 August. ${ }^{29}$ On 31 August it heard from H.J. Russell, the manager of the Newfoundland Railway, about the impact that Canadian freight rates would have on transportation services in Newfoundland:

Mr. Russell stated that the treatment of freight moving from North Sydney to Port-aux-Basques as all-rail traffic, together with the application of current Canadian freight rates, will cut the present Newfoundland rates in half and will be of considerable benefit to Newfoundland generally. Unfortunately North Sydney cannot handle all of our imports from Canada, and as a result a large proportion will still have to be carried by steamship at existing rates. To eliminate this and to ensure that those areas of Newfoundland which are serviced entirely by steamship will receive the benefit of reduced freight rates in the same proportion as the areas accessible to the railway, it will be necessary either to subsidize our steamship service or to endeavour to have the Maritime Freight Rates Act so extended as to make it applicable to the Steamship Services. ${ }^{30}$

In reply, he was told that the delegation "had already noted this point for further consideration." In its brief to the delegation, the St. John's Board of Trade likewise called for the extrapolation of the subsidy of the Maritime Freight Rates Act to the Newfoundland Railway's coastal services, a course of action for which there was no Canadian precedent. ${ }^{31}$

The preliminary work of the delegation in St. John's led to the drafting of a lengthy memorandum that the Newfoundland negotiators took with them for submission in Ottawa. ${ }^{32}$ Section IX of this document 
detailed the thinking of the delegation on the Newfoundland Railway and rejected the proposal of Canadian National Railways - made in a report included in the Black Books - that its projected Newfoundland operations should report to head office in Montreal through established regional headquarters in Moncton, New Brunswick. Because of its "insular position" and "geographical and climatic conditions," there should be a separate "Newfoundland Region" within the Canadian National system, with a regional manager in St. John's who would report directly to Montreal. Echoing the argument of the St. John's Board of Trade, section IX likewise called for the advantages of the Maritime Freight Rates Act to be extended "so as to include transfers to coastal steamers at terminals for delivery to all ports along the coast." In section XXI of its memorandum, the delegation proposed a change in what was on offer regarding the ferry service across Cabot Strait. This involved revising the words "Canada will maintain in accordance with the traffic offering a Steamship Service between North Sydney and Port-auxBasques" in clause 16(1) of the Grey Book to read "Canada will maintain in accordance with the traffic offering an efficient freight and passenger steamship service between North Sydney and Port-aux-Basques."This change, it was argued, was justified by the increased volume of business that Confederation would bring and the resultant increase in traffic between the two ports.

Ottawa prepared for the final talks as before: that is to say, through the mechanism of a cabinet committee on Newfoundland, which was advised by an interdepartmental committee, the latter chaired for this round by the Under-Secretary of State for External Affairs with MacKay as vice-chairman. ${ }^{33}$ The interdepartmental committee appointed subcommittees and one of them, chaired by Deputy Minister of Transport J.C. Lessard, had as its mandate transportation and communications. ${ }^{34}$ The formal opening of talks between the Newfoundland and Canadian delegations took place in the Senate Chamber, Ottawa, on 6 October 1948, with St. Laurent and Walsh acting as co-chairmen. ${ }^{35}$ Early on in the proceedings, the Newfoundlanders presented their memorandum as two parts, the first part dealing with 
financial matters and the second with everything else. ${ }^{36}$ As events unfolded, Canada rejected all three of the changes the Newfoundland side wanted vis-à-vis the railway and gulf ferry service. No provision was made for a separate Newfoundland region of Canadian National Railways, and the proposals to extrapolate subsidized rail freight rates to coastal services and change the wording regarding the North SydneyPort aux Basques link were refused. According to Lessard, Newfoundland would have all the protection it needed under section 312 of the Railway Act, 1919, which, of course, applied to the whole of Canada. ${ }^{37}$ To the extent possible, it seemed Ottawa's intention was that Newfoundland should fit within the existing federal framework.

Thus, when the final Terms of Union were signed in Ottawa on 11 December 1948, the provisions relating to the Newfoundland Railway were reworded but not fundamentally changed from those in the offer sent to the National Convention in $1947 .{ }^{38}$ Clause 5 of that offer emerged as Term 31 in the final document, clause 16 as Term 32, and clause 8 as Term 33. In Term 31 the Newfoundland Railway remained at the head of the list of 13 services to be taken over by the government of Canada and in Term 33 it remained first on the list of Newfoundland properties to become property of Canada (but with the reference to ships under construction in the United Kingdom dropped). In Term 32, section (1) remained as before but sections (2) and (3) were reworked with the reference to the Board of Transport Commissioners dropped. The final text of Term 32, which became the subject of much litigation in later years, was as follows:

32 (1) Canada will maintain in accordance with the traffic offering a freight and passenger steamship service between North Sydney and Port aux Basques, which, on completion of a motor highway between Corner Brook and Port aux Basques, will include suitable provision for the carriage of motor vehicles.

(2) For the purpose of railway rate regulation the Island of Newfoundland will be included in the Maritime 
region of Canada, and through-traffic moving between North Sydney and Port aux Basques will be treated as allrail traffic.

(3) All legislation of the Parliament of Canada providing for special rates on traffic moving within, into, or out of, the Maritime region will, as far as appropriate, be made applicable to the Island of Newfoundland.

On the same day that the Terms of Union were signed, the Government of Canada published Statements on questions raised by the Nerwfoundland delegation during the negotiations for the union of Newfoundland with Canada (Ottawa: King's Printer, 1948). This 14-page collection covered matters that had come up in the negotiations but were "scarcely of a constitutional nature" and therefore not the stuff of "formal terms of union." Item xiv dealt with the Newfoundland Railway and made this commitment: "After the date of Union, the Canadian National Railways will be entrusted with the responsibility of operating the Newfoundland Railway and Coastal Steamship Services, and it will be their responsibility to see that services are furnished commensurate with the traffic offering." In February 1949, the Statute Law Amendment (Newfoundland) Act, which incorporated the changes to the Maritime Freight Rates Act, made necessary by Term 32, was passed by the Parliament of Canada. ${ }^{39}$ Finally, all required approval of the Terms of Union having been given, "immediately before the expiration of the thirty-first day of March, 1949" Newfoundland actually became a province of Canada, the tenth in the country.

The next day, the recently knighted Sir Albert Walsh, the first lieutenant-governor of the province of Newfoundland, swore in J.R. Smallwood as its first premier; the first provincial election was then held on 27 May. On 1 April also, by Order-in-Council, the Canadian government entrusted the management and operation of the Newfoundland Railway to Canadian National Railways "upon such terms and subject to such regulations and conditions" as it might "from time to time" decide upon. ${ }^{40}$ For its part, Canadian National, acting 
within the Canadian regulatory framework, issued a rate schedule for Newfoundland - there was no general Maritime rate - that would be subject to the subsidy provided for in the Maritime Freight Rates Act. ${ }^{41}$

Seemingly, a smooth transition had been made in terms of railway administration and service. But during the campaign leading to the May provincial election, Smallwood heard from Philip Gruchy, the manager of the Anglo-Newfoundland Development Company's pulp and paper mill at Grand Falls and a signatory to the Terms of Union with Canada, that the freight rates Canadian National was charging in Newfoundland "were in many cases higher, and in some cases considerably higher," than those in effect in the Maritime provinces. ${ }^{42}$ In Gruchy's view this constituted "a serious violation" of subsections 2 and 3 of Term 32 . When Smallwood asked for details, he was shocked by what he heard back, but with Gruchy's co-operation he was able to keep the matter quiet during the election campaign, thereby denying his opponents an opening to claim that the Canadian government was "beginning to violate the Terms of Union." ${ }^{43}$ The premier promised Gruchy that he would deal with the matter as soon as possible after the election, which Smallwood's Liberal Party won handily. Following the vote, the government engaged prominent St. John's lawyer Philip J. (Phil) Lewis to handle the Newfoundland case, with a view to making representations in Ottawa. Thanks to his work on this assignment, Lewis quickly acquired the reputation of being the province's leading expert on the transportation arrangements made in the Terms of Union. ${ }^{44}$

After visiting Newfoundland 1-12 July 1949, Defence Minister Brooke Claxton reported to St. Laurent (prime minister since 15 November 1948) that while the people of the new province were more reconciled to union than he had thought possible, railway rates were a sore issue. The railway itself was "indescribable": 
It seems to me quite out of the question to think of putting in a standard gauge. I think the best course to follow would be to straighten out some of the worst curves, reduce the grades and strengthen the bridges so as to take longer trains, the maximum loads now appearing to be eight or nine cars. The rails are in terrible condition, already short rails are flattened at both ends. It is almost impossible to read on the train. It takes 26 hours and 40 minutes of scheduled run from St. John's to Port au[x] Basques over the whole length of lines. The people recognize that C.N.R. has been doing a good job since taking over the railways. For the first time most of the trains are beginning to run on schedule.

Yet, though rates were cheaper than before union, people felt "that they should have the same rates as those in effect in the Maritimes." ${ }^{45}$ There was "no such thing as a Maritime rate as a general class" and Newfoundland was now enjoying the benefit of the application of the Maritime Freight Rates Act to relevant charges. Nevertheless, there was a movement afoot for redress.

Claxton's expectation was that Newfoundland's representations on the matter would receive "the most sympathetic consideration," but in fact a rocky road lay ahead, as Newfoundland adjusted to the complex new reality of federal-provincial relations. In September 1949, Smallwood. Lewis, and Attorney General Leslie R. Curtis went to Ottawa with representatives of the Anglo-Newfoundland Development Company, Buchans Mining Company, Bowater Pulp and Paper Mills Company (Corner Brook), and Associated Newfoundland Industries (St. John's). ${ }^{46}$ Two briefs seeking redress were presented to Transport Minister Lionel Chevrier, one by the Newfoundland government and one by the business representatives present. For his part, Chevrier undertook to take the matter up with his government colleagues.

While this matter was pending, the Royal Commission on Transportation - the first such Canadian body to visit Newfoundland held hearings in St. John's from 27 to 29 September. Appointed on 29 
December 1948, the Commission was Ottawa's answer to the rising tide of complaint in Canada about higher freight rates in the post-war period. It was chaired by former Chief Justice of Saskatchewan W.F.A. Turgeon and had as its other members the distinguished academics Henry Forbes Angus (University of British Columbia) and Harold Adams Innis (University of Toronto), the author of The Cod Fisheries: The History of an International Economy, published in 1940. In welcoming the commissioners to Newfoundland at the start of their hearings, Smallwood observed that "for purposes of railway rate regulation" the Terms of Union had put Newfoundland in the Maritime region and that the province was entitled to exactly what that region got, "no more and no less." ${ }^{\prime 7}$ Barring a change in the relevant provision of the Terms of Union, he said in clear and unmistakeable language, "we stand or fall by what the maritime region generally may get."

Following on from Smallwood's remarks, the Newfoundland government's brief to the Royal Commission was presented by Lewis and read aloud by businessman George McNamara, who had assisted in its preparation. In his introductory comments, Lewis reiterated what Smallwood had said regarding railways rates: "It is generally accepted ... that the freight rate structure applicable to the maritime region is automatically effective in Newfoundland and that this province is entitled to freight rate privileges, no better and no worse than those obtaining in the maritime region." ${ }^{48}$ The Newfoundland brief, he explained, dealt with matters of "general application" but did not deal with "the question of freight rates, as such." This approach was "consistent with the policy of government," which was "based upon the principle" that the "application of freight rates" to the province was "a matter incidental to the interpretation of the terms of union" and therefore "a question for settlement between the central and the provincial governments." Once the principle of equality as between $\mathrm{New}^{-}$ foundland and the Maritime provinces was accepted by the two levels of government, it would be up to the Board of Transport Commissioners to formulate an actual schedule of rates.

On 4 October, having heard from Chevrier that Ottawa wanted to 
refer the freight rates issue to the Board of Transport Commissioners for decision, Smallwood followed the same line of argument in a letter to St. Laurent, intended to be "off the record" lest the matter "be flung to the Opposition." ${ }^{49}$ While he was "clearly not a constitutional lawyer," Smallwood ventured, the reference now suggested to the Board of Transport Commissioners struck him "as being altogether wrong":

Surely, what we have here is a question of interpreting the B.N.A. Act, and unless I am on the wrong track the Board has no jurisdiction in such a matter. The Terms of Union were made by the Government of Canada and the Government of Newfoundland, and enacted by the Parliament of the United Kingdom. We, for our part, say that one of the Terms or clauses in this Act is being violated by the C.N.R. Through Mr. Chevrier we ask the Government of Canada if they agree that this violation has taken place. If the Government of Canada agree that the violation has occurred, then I suppose the next step is that they inform the C.N.R. and instruct them to effect rates in conformity with our mutual interpretation of the clause in question. If, on the other hand, the two Governments cannot agree on the meaning of the clause in question then, surely, the procedure is to refer it to somebody having jurisdiction in the matter of interpreting the B.N.A. Act. True, there is such a body as the Board of Transport Commissioners set up to deal with Railway matters as such, but suppose the alleged violation had occurred in a matter to deal with which no particular body had been set up. In that case how would the matter be resolved?

I am only thinking aloud in this matter, but it does seems to me that it is a matter of interpreting the B.N.A. Act, and if the two Governments concerned are unable to agree on the interpretation then surely it becomes a matter for the Supreme Court of Canada, or possibly the Exchequer Court of Canada. 
With all the interests concerned pressing him "to know what is to happen in the matter," Smallwood sought St. Laurent's advice and asked for "an early reply." "I am trying," he cautioned, "to prevent this matter from becoming a political football."

St. Laurent's reply gave nothing and was in keeping with the intention on the Canadian side in the negotiation of the Terms of Union that, to the extent possible, Newfoundland would fit within the existing framework of Canadian federalism. While the Board of Transport Commissioners was not mentioned in the Terms of Union, it had been specifically referred to in the offer sent to the National Convention in 1947. In sum, the Newfoundland side had been left in no doubt about how railway freight issues were dealt with in Canada. Accordingly, St. Laurent told Smallwood that there was nothing he could add to the letter the premier had received from Chevrier: "We do not feel it would be appropriate for us, in so intricate a matter, to reach a decision as to what the proper freight rates should be. If, as you suggest, a point of law is involved, and the provincial authorities should not be satisfied by the decision of the Board of Transport Commissioners, they would, as Mr. Chevrier indicated, have the right of appeal by leave to the Supreme Court." ${ }^{50}$ For the Canadian government to adopt any other course in the matter "would be tantamount to an attempt ... to assume judicial functions" it did not possess. The way to ensure that the issue that had arisen did not become "a political football" was to have it "determined by the appropriate tribunals."

Smallwood got the message, and the province forthwith applied to the Board of Transport Commissioners for an order directing Canadian National to cancel its existing Newfoundland tariff schedule and replace it with charges based on current Maritime rates. Newfoundland was represented before the board by Attorney General Curtis and Phil Lewis and Canadian National by A.K. Dysart and A.H. Hart. Argument was heard in Ottawa on 14 December 1949, and on 14 February 1950 the Board ruled on "all that the parties ... wish to have at present," namely, a decision as to whether Term 32(2) and (3) precluded Canadian National "from exercising in Newfoundland the right 
which it would otherwise have under the Railway Act ... to discriminate in rates because of dissimilarity in circumstances and conditions. ${ }^{\text {51 }}$ In the Board's view it was "expedient to decide this preliminary question before proceeding further with the case." Its answer to the immediate question before it was "No"; while Term 32(2) might mean that rates in Newfoundland had to be "in general conformity with the rate structure in the other Maritime Provinces," it did not negate the principles on which it had previously acted "in regard to discrimination under the provisions of the Railway Act."

This was an unpromising start for Newfoundland but, following further hearings in St. John's and Ottawa, the Board issued a second decision in the case on 22 January $1951 .{ }^{52}$ The Board now upheld the basic Newfoundland claim and rejected Canadian National's contention that the Terms of Union did not "go beyond making applicable, in every relevant respect, the benefits of the Maritime Freight Rates Act." Applying this narrow interpretation, the railway had "included a socalled surcharge in support of which it contended that extra handling charges were involved in the transferring of traffic at Port aux Basques," an action that was "strenuously opposed by the Province." The finding of the Board was that "notwithstanding certain dissimilar, disadvantageous circumstance and conditions pertaining to Newfoundland," under Term 32 the province was "to be included rate-wise in the Maritime region on a general level of rates similar to the other Maritime Provinces." Moreover, "as a Special Act," the Terms of Union took precedence over "any provisions of the Railway Act to the contrary."

Based on these conclusions, the Board directed Canadian National to come up with a revised rate schedule for Newfoundland to take effect on 1 March 1951. The first of three conditions specified for this was the "removal of the so-called surcharges." ${ }^{3}$ Under this dispensation, Term 32(2) was "interpreted to require the extrapolation to points in Newfoundland on a mileage basis, of rates applicable from Central Canada to the Maritime Provinces." ${ }^{54}$ Rates constructed accordingly were to be "maximum rates," that is, "CN could not charge rates to Newfoundland higher than those constructed according to Term 
32(2)." 55 Newfoundland subsequently sought compensation for the amount Canadian National had overcharged shippers after 1 April 1949, but this claim met a cool reception in Ottawa (though the federal government made a detailed response, those details are buried in a heavily redacted Department of Justice file — one of many — in the holdings of Library and Archives Canada in Ottawa). ${ }^{56}$

Following his success before the Board, Lewis ran as a Liberal candidate in the provincial general election held on 26 November 1951. He was elected in the two-member riding of Harbour MainBell Island and from 1951 to 1971 sat in the Smallwood cabinet as a minister without portfolio. In 1953, Smallwood raised with St. Laurent the matter of compensation for the excess charges that Canadian National had imposed on Newfoundland shippers between 1949 and 1951, but this claim did not succeed. In 1966, Lewis chaired a provincial Royal Commission on Transportation. Its report described "the Newfoundland Freight Rates Case of 1951" as "the Magna Carta of Newfoundland insofar as its rail formula is concerned." ${ }^{57}$ Accordingly, it was of "transcendent importance" to the province that the freight rate structure achieved through this case "be retained intact." ${ }^{38}$

By this time, Newfoundland was witnessing the start of a transportation revolution, which in a few years would leave the railway age behind. In 1965, in one of its finest achievements, the Smallwood government completed the paving of the Trans-Canada Highway across Newfoundland from St. John's to Port aux Basques, a development that had decidedly negative consequences for Canadian National's rail operations in the province. Passenger service on the main line of the Newfoundland railway ended in 1969 after the national carrier had introduced a trans-island bus service (CN Roadcruiser). In 1978 Canadian National spun off its east coast ferry operations to a subsidiary, CN Marine. The next year it assigned its Newfoundland land operations - rail, bus, and trucking — to another subsidiary, Terra Transport. Meanwhile, in 
1977, with the shift from rail to road well advanced, Memorial University psychology professor Arthur M. Sullivan ${ }^{59}$ was named by Ottawa to lead a one-person Commission of Inquiry into Newfoundland Transportation. ${ }^{60}$ In recommendation 29 of his 1978 report, he called for an immediate start on planning "to phase out the railway in Newfoundland in approximately ten years." ${ }^{\prime 1}$ In actual fact the railway was abandoned exactly a decade later under the terms of a federalprovincial agreement popularly known as "Roads for Rails." ${ }^{22}$ In the memorandum of understanding between the two governments, Term 32(2) was referenced in two sections:

3. The Minister of Transport for Canada undertakes, through $\mathrm{CNR}$, to maintain, consistent with changing market conditions, an active and ongoing freight presence in the Newfoundland market; and the Governor in Council, pursuant to Section 99 of the Financial Administration Act (Canada), has directed CNR to develop and apply, with such modifications as may be required to effect an orderly transition from rail to an inter-modal system, freight rates for its through inter-modal freight traffic to, from, and on the Island of Newfoundland that are based on the principles set out in Term 32 (2) of the Terms of Union with Newfoundland. Order in Council, P.C. 1988-1202 dated June 16, 1988.

9. It is agreed that nothing herein shall prejudice the legal position either party may wish to take with respect to Term 32 (2) of the Terms of Union at any time following the closure of the Newfoundland Railway, except with regard to providing and maintaining a railway in Newfoundland. ${ }^{63}$

Canadian National got to close down a burdensome rail line, while maintaining responsibility under Term 32(1) for the Gulf ferry service, and the province got an infusion of cash to improve transportation infrastructure. The deal was billed both in Ottawa and St. John's 
as win/win. Transportation of goods to Newfoundland via the North Sydney-Port aux Basques ferry would now be by container or boxcar, with railway rates applied to Newfoundland destinations now involving rail, water, and truck transportation. Moreover, in an increasingly competitive environment under the National Transportation Act, 1987, railway rates in Canada were often buried in confidential contracts. The 1987 Act updated the National Transportation Act of 1967, under which the Board of Transport Commissioners had been replaced by the Canadian Transport Commission. ${ }^{64}$ Under the 1987 Act, a successor body, the National Transportation Agency (NTA), was launched.

On 6 July 1989, the meaning of Term 32 in the new transportation and regulatory environments was tested when Atlantic Container Express Inc. (ACE), a Montreal-based ocean shipping company with container service to St. John's and a competitor of Canadian National — the two had a history of regulatory battle - filed a complaint with the fledgling NTA.$^{65}$ In 1982 ACE had complained to the Minister of Transport that some Canadian National freight rates to Newfoundland were non-compensatory (i.e., constituted unfair competition). ${ }^{66}$ The complaint had led to an investigation by the Railway Transport Committee of the Canadian Transport Commission and four interim orders in favour of the complainant. ${ }^{67}$ The last of these, issued after public hearings had been held in Montreal and St. John's in October 1984, had triggered a petition to the federal cabinet by Canadian National and the issuance of Privy Council Order No. 1985-575, dated 19 February 1985. This order had suspended the rate increases ordered by the regulator until such time as it had concluded "a full and comprehensive investigation ... of all matters related to the compensatory rate issue on all traffic between mainland Canada and Newfoundland." ${ }^{68}$ Then, on 14 February 1986, having completed its investigation, the Railway Transport Committee had issued a further order (No. R-39045) reining in the railway. ${ }^{69}$ Newfoundland had immediately applied for review of this order, and on 28 August 1987 the regulator had issued a further ruling. This had set out a methodology to be 
followed by Canadian National in constructing rates to ensure compliance with the Terms of Union, which took precedence over the statutory requirements of the Railway Act.

ACE's 1989 complaint, however, maintained that Canadian National was still offside and was "charging rates to Newfoundland destinations not consistent with the requirements of the Terms of Union." ${ }^{70}$ Specifically, the company complained about rates being charged by Canadian National "on pool car traffic from Toronto and Montreal, ... on insulation from Ottawa, and ... on flour from Montreal.” These, it was maintained, were not compensatory and were "at less than the level required by the Terms of Union." ${ }^{71}$ In response, the NTA, having issued a first decision in the matter on 3 October 1989, held public hearings in St. John's (14 and 15 August 1990) and Corner Brook (20 and 21 August 1990) to determine how Term 32(2) "should be applied in establishing rates for the transportation of goods to Newfoundland, within the new regulatory regime" created by the 1987 Act. $^{72}$ In its decision, dated 22 May 1991, the agency agreed that "Terms of Union rates, based on Maritime rates ... should be developed using rail mileages through North Sydney to Port aux Basques and onto St. John's, as if the Newfoundland Railway was still in place." Canadian National was directed to act accordingly, while being authorized to "move freight to Newfoundland by any manner and any route."73 On 19 June 1991 Newfoundland applied to the Federal Court of Appeal for leave to appeal this decision. The province maintained that in its decision the NTA had erred in law in five matters and consequently had not given full effect to Term 32; "important constitutional issues" were at stake that affected "the public interest in respect of all shippers, receivers and residents of Newfoundland." On 2 September 1992 the Court acceded to Newfoundland's leave application but on 30 April 1996 the province discontinued its appeal. ${ }^{74}$

Meanwhile, on 6 May 1992, the NTA — after receiving detailed information from Canadian National, issuing an interim report dated 13 February, and hearing from all interested parties — had issued a further decision. ${ }^{75}$ This concluded that "the Terms of Union rate development 
methodology" described in the 1991 decision would "continue to provide Newfoundland with a constitutionally mandated and competitive rate structure that integrates the mainland conditions": "The intent of term 32(2) was to provide maximum rate protection to Newfoundland so that the province would not be disadvantaged by its distance from the mainland." In a further ruling in the same case on 26 November 1992, the NTA made known that it would "determine all complaints on Terms of Union rates and corresponding compensatory costs" based on the methodology in its 22 May 1991 decision. ${ }^{76}$ In sum, in the wake of the Roads for Rails agreement and in a time of transformed transportation arrangements, the NTA held that Term 32(2) was alive, well, and workable, even in the absence of rail service across Newfoundland.

In February 1995, with the political climate favouring further deregulation, the subsidies provided under the Maritime Freight Rates Act were ended. In June of that year a bill for legislation to be known as the Canada Transportation Act was introduced into Parliament. It received royal assent on 29 May 1996 and under its terms the NTA became the Canadian Transportation Agency (CTA). In a prefatory declaration the Canada Transportation Act held up "competition and market forces ... whenever possible" as the "prime agents in providing viable and effective transportation services." 77 A further test of Term 32(2) followed when, in 1997, Gordon Moffatt, the owner of a company that moved containers between central Canada and Newfoundland, asked the CTA for final offer arbitration in a dispute he had in progress with Canadian National over shipping rates applied to his traffic. ${ }^{78}$ Under the relevant section of its governing legislation, the CTA was required to refer the matter to an arbitrator chosen by the two parties or, failing that, an arbitrator of its own choosing.

In this case, however, before referring the dispute to arbitration, the agency ruled on the applicability in existing circumstances of Term 32(2). Counsel for Canadian National argued that "Term 32(2) had no further application after closure of the Newfoundland Railway in 1988"; that there was "no longer any relevant railway rate regulation to which Term 32(2) could apply"; and that because the company was no 
longer a Crown corporation — it had been privatized in 1995 - there was no law binding it "to implement Term 32(2) in its rate making with respect to movements to Newfoundland that include[d] rail transportation." ${ }^{79}$ But the CTA, while acknowledging that the "identification of a Maritime rate structure" had become difficult with "the majority of railway traffic" now moving under "rules contained in confidential contracts," nevertheless ruled on 2 June 1999 that the Constitution of Canada required "Terms of Union rates" (the British North America Act, 1949, which incorporated the Terms of Union, was included in the schedule to the Constitution Act, 1982 and renamed the Newfoundland Act) ${ }^{80}$ In brief, the CTA ruled:

that Term 32(2) continued to apply to Mr. Moffatt's traffic and that $\mathrm{CN}$ had obligations under Term 32(2). While acknowledging that the development of a Maritime rate structure may be a difficult task for an arbitrator and that the arbitrator may not have expertise in rate matters, the Agency concluded that the arbitrator could use his own resources or ask for assistance from the Agency. It, therefore, submitted the matter for arbitration, assigning the task of developing a Maritime rate structure and Terms of Union rates to the arbitrator, reminding the arbitrator that the Terms of Union are mandatory and a paramount consideration in the arbitration. ${ }^{81}$

Term 32(2) applied to rates even if in practice this meant a "best guess figure." 82

Canadian National appealed this outcome and in a decision dated 31 October 2001, written by Justice Marshall E. Rothstein and concurred in by Chief Justice John D. Richard and Justice Marc Noël, the Federal Court of Appeal decided in favour of the railway company. ${ }^{83}$ Term 32(2), Rothstein wrote, did not "of itself" require rate regulation. While it was true that the opening words "For the purpose of rate regulation" presumed "the existence of rate regulation that is relevant 
to the balance of the Term," these words did "not mandate that Parliament enact or maintain such regulation." For Term 32(2) to be operative there had to "exist some relevant railway rate regulation in legislation" administered by the CTA. In fact, in the existing "deregulated environment," no such regulation existed: "The notion of a Maritime rate structure had become an anachronism and there was no basis upon which to establish a realistic Maritime rate structure from which could be extrapolated rates to Newfoundland." It was unreasonable "to conclude that the Constitution of Canada would require that regulation of freight rates would be based on 'best guess' figures." And while it was true that the Constitution as "the supreme law of Canada" had to be "adapted to conditions that did not exist when its various provisions were enacted," the "living tree doctrine" - Lord Sankey's famous dictum in the 1929 Persons Case (Edwards v. Canada [Attorney General]) - could not "be stretched to animate a provision that is a practical anachronism." In the circumstances the application of Term 32(2) was "suspended," pending the provision of "relevant rate regulation." A constitutional Gordian knot had been surgically cut.

But what about rates on the "freight and passenger steamship service" Ottawa was constitutionally obligated by Term 32(1) to maintain between North Sydney and Port aux Basques "in accordance with the traffic offering"? And what was now meant by the commitment in Term 32(2) with respect to railway rate regulation to include "the Island of Newfoundland ... in the Maritime region of Canada" and to treat "through-traffic moving between North Sydney and Port aux Basques" as "all-rail traffic." In February 2016 this leftover business was tested in a case started by Oceanex, a short-sea shipping company formed in 1990 through the merger of ACE and Atlantic Searoute Partnership of Halifax. Oceanex operated between mainland Canadian ports and St. John's and was the main competitor of Marine Atlantic Inc. (MAI), the subsidized Crown entity currently operating the ferry 
service on the North Sydney-Port aux Basques route pursuant to Term 32(1).$^{84}$ In an application to the Federal Court of Canada, Oceanex requested judicial review of commercial freight rates approved by the Minister of Transport for the Gulf service effective 1 April 2016. ${ }^{85}$ In approving these rates, Oceanex maintained, the minister had violated the National Transportation Policy (NTP) specified in the 1996 Canada Transportation Act. The approved rates had "an injurious effect" on the company and unduly reduced "its inherent advantages as a water transportation provider, contrary to the terms of the National Transportation Policy." Oceanex asked that the Court quash the approved rates and order the minister to "approve MAI commercial freight rates that are sufficient to fully recover its costs or, in the alternative, such level of subsidized rates as is necessary to maintain freight service between North Sydney and Port aux Basques in accordance with the Terms of Union, and is not injurious to Oceanex in accordance with ... the National Transportation Policy."

The case was heard by Justice Cecily Y. Strickland, who ruled against the company on 7 March 2018.86 "I am not persuaded," she wrote in passing, "that the NTP can serve to constrain the level of public costs assumed by Canada in meeting its constitutional obligation to provide for ferry services on the Constitutional Route as imposed by the Terms of Union." In sum, when it came to subsidy for MAI's Gulf ferry service between North Sydney and Port aux Basques, Term 32 trumped legislative requirement. As the Terms of Union were "clear" about the matter in dispute, Justice Strickland reasoned, it was not necessary "to resort to historical evidence" to decide the case. At the time of writing, her decision was before the Federal Court of Appeal.

In his useful March 2003 paper "The Terms of Union: An Analysis of Their Current Relevance," which he prepared for the Newfoundland and Labrador government's Royal Commission on Renewing and Strengthening Our Place in Canada, the St. John's lawyer and legal 
scholar Stephen May, QC, sensibly concluded that, overall, "the force and effect" of the Terms of Union had essentially been "spent." ${ }^{87}$ The much-litigated Term 32 is an exception. Under Term 32(1), Ottawa has a continuing obligation to maintain the Gulf ferry service on what Justice Strickland termed the "Constitutional Route." Moreover, pursuant to Justice Rothstein's searching decision in the Moffatt case, Newfoundland and Labrador has a continuing right to any relevant rate advantage that Ottawa might extend to the Maritime provinces, the force of Term 32(2) being "suspended" rather than "spent," though in practice this may be a distinction without a difference. Constitutionally, except as provided for in the Terms of Union, now mainly overtaken by the passage of time, Newfoundland and Labrador is a province comme les autres. This is what was intended in 1948 and has been acknowledged in the courts.

On 11 February 1985 the government of Newfoundland and Labrador and the government of Canada signed a memorandum of agreement "on joint management of the offshore oil and gas resources off Newfoundland and Labrador and the sharing of revenue from the exploitation of these resources." ${ }^{88}$ Known as the Atlantic Accord, this memorandum was arguably the most important document negotiated between Ottawa and St. John's since the 1948 Terms of Union. Under section 64, Ottawa agreed that, "should the Government of Newfoundland and Labrador achieve the requisite support among the other provinces for the constitutional entrenchment of the Accord ... it would introduce a mutually agreeable resolution into Parliament." No such resolution has ever been introduced, and securing the "requisite support" would obviously be a formidable challenge in a country as regionally conflicted as Canada. Except under section 43 of the amendment procedure in the Constitution Act, 1982, which covers amendment "to any provision that applies to one or more, but not all provinces," it is hard to get something new into the Canadian Constitution. ${ }^{89}$ This is all the more reason to appreciate and understand what is already in that document. In the case of Newfoundland and Labrador, it would always be instructive to start 
with the constitutionally entrenched Terms of Union, especially the tangled history of Term 32.

\section{Acknowledgements}

I am grateful for research assistance to Dr. Melvin Baker of St. John's, Newfoundland and Labrador; and John Sadler, director of the John \& Dotsa Bitove Family Law Library at the University of Western Ontario, London, Ontario. I thank Jock Bates of Victoria, British Columbia, for editorial advice, and the Honourable Marshall E. Rothstein of Vancouver for reading my first draft. I learn much about the law from Professor Robert E. Hawkins of the Johnson Shoyama Graduate School of Public Policy, University of Regina, Regina, Saskatchewan.

\section{Notes}

1 Jeffrey F. Collins, "Executive Federalism and the Terms of Union: A New Approach to Understanding the 'Roads-for-Rails' and 'Roadsfor-Boats' Agreements," Newfoundland and Labrador Studies 27, no. 2 (Fall 2012): 157-78.

2 For a general account of the history of Newfoundland in the immediate post-Second World War period, see my Newfoundland in the North Atlantic World, 1929-1949 (Montreal and Kingston: McGill-Queen's University Press, 1988).

3 Acts of the Commission of Government, 1946, 115.

4 This account of the railway draws on information in Library and Archives Canada (LAC), RG12 (Records of the Department of Transport), vol. 2595, file 104-5-1 (part 1), "Newfoundland Railway and Steamship Services"; and Meeting between delegates for the National Convention of Nerwfoundland and representatives of the Government of Canada::] Ottawa, June25th-September 29th, 1947 (hereafter Meeting between delegates ... 1947), Part I (Summary of Proceedings), Appendix II, "Memorandum presented by the Newfoundland delegation at the commencement of the discussions, outlining services which, in the event of union, would appear to fall in the federal sphere." 
5 For details of this, see Malcolm MacLeod, "Subsidized Steamers to a Foreign Country: Canada and Newfoundland, 1892-1949," Acadiensis 14, no. 2 (Spring 1985): 66-92.

6 Meeting between delegates ... 1947, Part I (Summary of Proceedings), Appendix II, 19.

7 See James K. Hiller and Michael Harrington, eds., The Nerfoundland National Convention 1946-1948 (Montreal and Kingston: McGillQueen's University Press, 1995), vol. 2, Reports and Papers, "Report of the Transportation and Communications Committee," 75-153. For the section on the railway, see 103-18.

8 Paul Bridle, ed., Documents on Relations between Canada and Newfoundland (Department of External Affairs, 1984), vol. 2, part 1, 398-99.

9 Ibid., 522-35.

10 Ibid., 535-38.

11 Ibid., 171-72.

12 Ibid., 245-48.

13 The archival reference is MG30, E159.

14 Meeting between delegates ... 1947, Part I (Summary of Proceedings), 6.

15 Ibid., 7.

16 Ibid., 8.

17 Ibid., 9.

18 LAC, MG30, E159 (R.A. MacKay fonds), vol. 5, file "Draft Committee Meetings, Rough Drafts of Proposals, 1947.”

19 Ibid.

20 Bridle, ed., Documents, vol. 2, part 1, 648.

21 Ibid., 649-51.

22 For these events, see Neary, Newfoundland in the North Atlantic World, 309-10.

23 Proposed Arrangements for the Entry of Newfoundland into Confederation [:] Terms believed to constitute a fair and equitable basis for union of Nerwfoundland with Canada should the people of Newfoundland desire to enter into confederation [,] October 29,1947 (Ottawa: King's Printer, 1948), 3.

24 See T. Stephen Henderson, "A Defensive Alliance: The Maritime Provinces and the Turgeon Commission on Transportation, 19481951," Acadiensis 35, no. 2 (Spring 2006): 46-64 (https://journals.lib. 
unb.ca/index.php/acadiensis/article/view/10598/11213).

25 Bridle, Documents, vol. 2, part 1, 723.

26 Ibid., 793-99.

27 Acts of the Commission of Government, 1948, 49.

28 Under Commission of Government, three of the commissioners were drawn from the United Kingdom and three from Newfoundland. Walsh had been appointed a commissioner on 5 September 1944.

29 The minutes of the meetings are in The Rooms Provincial Archives (RPA), St. John's, GN154 (Newfoundland Delegation to Ottawa, 1948), box, 1.

30 Bridle, ed., Documents, vol. 2, part 2, 1030.

31 A copy of the brief is in RPA, Albert J. Walsh Papers, MG302.23.

32 For a transcription of this document, see Melvin Baker and Peter Neary, "Negotiating Final Terms of Union with Canada: The Memorandum Submitted by the Newfoundland Delegation, Ottawa, 13 October 1948," Nerwfoundland and Labrador Studies 38, no. 2 (2018): 459-506. An original copy of the memorandum is in RPA, Albert J. Walsh Papers, MG302.40.

33 The first meeting, with MacKay in the chair, was held on 19 August. For the minutes, see LAC, RG 12 (Department of Transport), vol. 2595, file 104-5-1 (part 3).

34 Bridle, Documents, vol. 2, part 2, 1106.

35 Ibid., 1117.

36 For the financial part of the delegation's memorandum, see ibid., 1127-30.

37 LAC, RG 12, vol. 2595, file 104-5-1, part 5, Newfoundland Negotiations Minister's Copy.

38 For the final Terms of Union, see British North America Act, 1949 (since 1982 the Newfoundland Act) in United Kingdom, Public General Statutes, 1949, vol. 1, chap. 22, 52-57.

39 Statutes of Canada, 1949, vol. 1, chap. 6, 37-58.

40 PC 1454. I am grateful to Peter O'Flaherty, QC, for a copy of the order.

41 For the evolution of freight rates in post-Confederation Newfoundland, see LAC, RG13 (Department of Justice), vol. 2989, file 9-166726, "Statement Showing First Class Freight Rates in Cents per 
100 lbs. from Toronto, Ont. and Montreal, Que. to North Sydney, N.S. and Representative Destinations in Newfoundland" and RG30-A-1-C (Canadian National Railways), vol. 13217, file 9717-5, 1949-1957, "Newfoundland Freight Rates," memorandum enclosed in Asst. General Freight Traffic Manager to Vaughan, 8 May 1957.

42 Memorial University Libraries, Archives and Special Collections (ASC), COLL-075 (J.R. Smallwood Papers), file 3.10.013, Smallwood to St. Laurent, 4 Oct. 1949.

43 Ibid.

44 Having gone to sea as a young man, Lewis prided himself on being the only lawyer practising in St. John's to also have a first mate's certificate. His dual qualification made him Newfoundland's leading maritime lawyer. I am grateful to John Lewis for biographical information about his father. LAC, MG 32-B5 (Brooke Claxton fonds), vol. 117, file "Newfoundland: Miscellaneous 1948-1949," Memorandum to the Prime Minister, 21 July 1949.

46 LAC, RG30-A-1-C, vol. 13217, file 9717-5, 1949-1957, C.L. McCoy (General Freight Agent), Memorandum of Conference held in office of Minister of Transport, 19 Sept. 1949; ASC, COLL-075, file 3.10.013, Smallwood to St. Laurent, 4 Oct. 1949.

47 LAC, RG 33 (Royal Commissions), Royal Commission on Transportation, 27 Sept. 1949, vol. 32, 6144.

48 Ibid., 6148.

49 ASC, COLL-075, Smallwood to St. Laurent, 4 Oct. 1949.

50 ASC, COLL-075, St. Laurent to Smallwood, 12 Oct. 1949.

51 K.D.M. Spence, ed., Canadian Railway and Transport Cases (Toronto: Canada Law Book Co., 1950), vol. 64, 352-53.

52 K.D.M. Spence, ed., Canadian Railway and Transport Cases (Toronto; Canada Law Book Co., 1954), vol. 67, 353-59.

53 Ibid., 358.

54 Federal Court of Appeal, Canadian National Railway Co. v. Moffatt, 31 Oct. 2001 (https://www.canlii.org/en/ca/fca/doc/2001/2001fca327/2001fca327.html).

55 Ibid.

56 LAC, RG13, vol. 2989, file 9-166726, Newfoundland Terms of Union 
S32 and S33. See also LAC, RG30-A-1-C, vol. 13217, file 9717-5, 1949-1957, General Solicitor to Gordon, 29 May 1952. The Newfoundland claim was backed up by an Act of the provincial legislature that vested all relevant individual claims in "Her Majesty in right of Newfoundland" (Statutes of Newfoundland, 1952, No. 76, Freight Claims (Vesting in Crown) Act, 297-98). I have launched a complaint under the Access to Information Act to have LAC, RG13, vol. 2989, file 9-166726, Newfoundland Terms of Union S32 and S33, opened to researchers.

57 Newfoundland, Report of the Royal Commission on Transportation, Sept. 1966, 20.

58 Ibid.

59 Son-in-law of Phil Lewis.

60 See Report of the Commission of Inquiry into Newfoundland Transportation, vol. 1, July 1978 (http://publications.gc.ca/collections/collection_2016/bcp-pco/T22-37-1978-1-1-eng.pdf); vol.2, Feb. 1979 (http://publications.gc.ca/collections/collection_2016/bcp-pco/ T22-37-1978-2-1-eng.pdf); Executive Summary, July 1978.

61 Executive Summary, July 1978, "List of Recommendations Contained in Report," viii.

62 See Toward 2000: A Newfoundland and Labrador Transportation Initiative, a copy of which is in the holdings of the Centre for Newfoundland Studies, Memorial University Libraries, St. John's.

63 "Memorandum of Understanding on the Newfoundland Transportation Initiatives," 20 June 1988 (copy courtesy Clerk of the Executive Council, Province of Newfoundland and Labrador).

64 It had "separate committees to handle the five modes of transportation: rail, air, water, motor vehicle and commodity pipeline (except oil products)" (https://www.otc-cta.gc.ca/eng/publication/at-heart-transportation-a-moving-history).

65 ACE was owned "jointly owned by Newfoundland Capital Corp. of Gander, the Harvey Group of St. John's and CSL Group Inc. of Montreal" (Globe and Mail, 19 Nov. 1984, IB9).

66 My account of this complaint and its aftermath is based on information in Canadian Transport Commission, Reports, 1987, Newfoundland (Attorney General) and Atlantic Container Express, Inc. (Re) 
[1987] C.T.C.R., 23-68.

67 The orders were numbers R-35150, 6 May 1983; R-35460, 3 Aug. 1983; R-37286, 10 Oct. 1984; and R-37611, 21 Dec. 1984 (LAC, RG2 [Privy Council Office], A1a, vol. 6063, PC 1985-575). See also Globe and Mail, 7 Jan. 1985, B16.

68 LAC, RG2, A1a, vol. 6063.

69 The order followed a decision dated 12 Feb. 1986.

70 National Transportation Commission, Decision No. 509-R-1989 (https://otc-cta.gc.ca/eng/ruling/509-r-1989).

71 National Transportation Commission, Decision No. 266-R-1991 (https://otc-cta.gc.ca/eng/ruling/266-r-1991).

72 Ibid.

73 Ibid.

74 The information given here is based on documents in the registry of the Federal Court of Appeal (91-A-2287), provided courtesy of Peter O'Flaherty, QC, and Jack O'Flaherty.

75 Canadian Transportation Agency, Decision No. 254-R-1992 (https:// www.otc-cta.gc.ca/eng/ruling/254-r-1992? wbdisable=true).

76 Canadian Transportation Agency, Decision No. 705-R-1992 (https:// www.otc-cta.gc.ca/eng/ruling/705-r-1992).

77 Statutes of Canada, 1996, C.10, section 5.

78 Canadian Transportation Agency, Decision No. 300-R-1999 (https:// otc-cta.gc.ca/eng/ruling/300-r-1999).

79 Federal Court of Appeal, Canadian National Railway Co. v. Moffatt, 31 Oct. 2001 (https://www.canlii.org/en/ca/fca/doc/2001/2001fca327/2001fca327.html).

80 Ibid.

81 Ibid.

82 Ibid.

83 Ibid.

84 In its 1980 report on Newfoundland, the Economic Council of Canada had noted that transportation subsidies, "by underwriting the cost of goods imported from the mainland" to Newfoundland, had "hindered the growth of import-competing industries." The Council had recommended "that the federal and provincial governments immediately enter into negotiations to establish a federal financial 
obligation to the Newfoundland government in place of the existing Gulf subsidy. They should also arrange to finance the adjustment of any workers directly affected by this action" (Economic Council of Canada, Newfoundland: From Dependency to Self-Reliance [Ottawa, 1980], 23).

85 Federal Court of Canada, Notice of Application, 26 Feb. 2016, file T-348-16.

86 Federal Court of Canada, Oceanex Inc. v. Canada (Minister of Transport), 7 Mar. 2018 (https://www.canlii.org/en/ca/fct/doc/2018/2018fc250/2018fc250.html). I served as an expert witness in this case, and the present paper draws on my affidavit.

87 See https://www.gov.nl.ca/publicat/royalcomm/research/May.pdf, 172.

88 See https://www.servicenl.gov.nl.ca/printer/publications/aa_mou.pdf.

89 For the complexity of constitutional amendment in Canada and its consequences, see R.E. Hawkins, "Constitutional Workarounds: Senate Reform and Other Examples," Canadian Bar Review 89, no. 3 (2011): 513-43. The amendments made to the Terms of Union in 1997,1998 , and 2001 were in accordance with section 43. 